\title{
Pengaruh Keberadaan Partikel Asing terhadap Karakteristik Medan Listrik pada GIS Equilateral Tiga Fasa
}

\author{
Rizki Wahyu Pratama ${ }^{*}$, Hanalde Andre ${ }^{1}$, Umar Khayam $^{2}$ \\ ${ }^{1}$ Jurusan Teknik Elektro, Fakultas Teknik, Universitas Andalas, Padang, Sumatera Barat, Indonesia \\ ${ }^{2}$ Jurusan Teknik Elektro, Sekolah Tinggi Elektro dan Informatika, Institut Teknologi Bandung \\ "Corresponding author, e-mail: rizkiwahyupratama@eng.unand.ac.id
}

\begin{abstract}
Abstrak - Paper ini menganalisa tentang pengaruh keberadaan partikel asing pada peralatan hubung isolasi gas/ gas insulated switchgear (GIS) 3 fasa susunan equilateral. Pada perhitungan ini, akan dianalisa karakteristik medan listrik pada GIS equilateral 3 fasa dengan memvariasikan letak partikel dalam tangki GIS. Partikel dimodelkan memiliki panjang $5 \mathrm{~mm}$ dan ketipisan $0.5 \mathrm{~mm}$ terletak di dalam GIS 3 fasa susunan equilateral dengan diameter tangki $150 \mathrm{~mm}$ dan diameter konduktor $25 \mathrm{~mm}$. Perhitungan medan listrik ditinjau pada beberapa titik dalam tangki GIS equilateral 3 fasa. Simulasi dan perhitungan medan listrik dilakukan dengan perangkat lunak menggunakan metode FEM. Hasil dari perhitungan menunjukkan adanya perbedaaan karakteristik medan listrik antara GIS normal dengan GIS yang terdapat partikel asing. Perbedaan karakteristik ini dapat dilihat pada besar medan listrik, dan rasio eksentrisitas pada beberapa titik tinjau keberadaan partikel.
\end{abstract}

Kata Kunci : gas insulated switchgear, equilateral, partikel asing, medan listrik, rasio eksentrisitas

\begin{abstract}
This paper analyzes the effect of the presence of foreign particles on an equilateral arrangement of 3 phase gas insulated switchgear (GIS) insulation equipment. In this calculation, the electric field characteristics will be analyzed in 3-phase equilateral GIS by varying the location of the particles in the GIS tank. Particles are modeled to have a length of $5 \mathrm{~mm}$ and a thickness of $0.5 \mathrm{~mm}$ located in a 3 phase GIS equilateral arrangement with a tank diameter of $150 \mathrm{~mm}$ and a conductor diameter of $25 \mathrm{~mm}$. The electric field calculations are reviewed at several points in the 3-phase equilateral GIS tank. The simulation and calculation of the electric field were calculated with FEM method software. The results of the calculations show that there are differences in the characteristics of the electric field between normal GIS and GIS where foreign particles are present. The difference in these characteristics can be seen in the magnitude of the electric field, and the ratio of eccentricity from some point of view.
\end{abstract}

Keywords : gas insulated switchgear, equilateral, foreign particles, electric field, eccentricity ratio

\section{Pendahuluan}

Telah terbukti secara luas bahwa Gas Insulated Switchgear (GIS) memiliki tingkat keandalan yang baik. Namun, partikel logam dalam GIS dapat mengurangi tingkat ketahanan sistem [1-11]. Partikel logam dalam GIS dapat berasal dari proses manufaktur dan berasal dari bagian yang bergerak dalam sistem atau dari getaran mekanik dll. Kedua partikel logam yang terletak di spacer atau pada elektroda GIS serta logam gratis partikel dapat menyebabkan peluahan sebahagian yang dapat menyebabkan flashover. Pada penelitian ini akan dianalisa pengaruh keberadaan partikel yang terletak pada beberapa posisi di dalam tangki GIS equilateral 3 fasa terhadap karakteristik medan listriknya.

Penggunaan peralatan tiga fasa (tiga fasa dalam satu tangki) seperti pada peralatan hubung berisolasi gas/ gas insulated switchgear (GIS) tiga fasa dan bus bar berisolasi gas/ gas insulated bus (GIB) tiga fasa, semakin meningkat karena kelebihan yang didapatkan dengan penggunaannya dalam sistem tenaga [1-11]. Keuntungan menggunakan busbar dengan konstruksi 3 fasa dalam satu tangki dibanding busbar dengan kontruksi 3 buah tangki 1 fasa yaitu [7]:

$>$ Pemakaian ruang lebih sedikit dan jumlah tangki lebih sedikit.

$>$ Pada kasus di tangki 3 fasa, busur antara fasatanah dalam selang beberapa milidetik, berubah menjadi gangguan fasa-fasa antar konduktor karena adanya medan pada fasa lain dan saat itu juga busur fasa-tanah menghilang.

Untuk parameter sama (tegangan, ukuran konduktor sama, jarak antar fasa dan jarak fasa ke ground), resultan stress medan pada tangki 3 fasa kira-kira $30 \%$ lebih kecil dari tangki 1 fasa. 


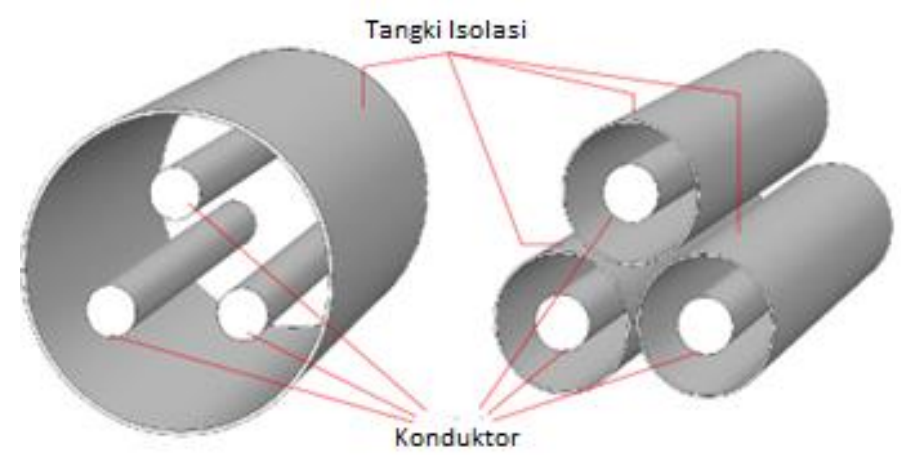

Gambar 1. Konstruksi GIS 3 Fasa dan GIS 1 Fasa.

Peralatan listrik 3 fasa berbeda dengan peralatan 1 fasa dari dua aspek, yaitu konfigurasi peralatan dan tegangan yang dipakai [1-6], seperti terlihat pada Gambar 1 dan Gambar 2. Hal ini menyebabkan karakteristik medan listrik peralatan tiga fasa berbeda dengan peralatan satu fasa [1-6]. Perbedaan ini akan diselidiki pada bagian bus bar dari peralatan hubung isolasi gas/ gas insulated switchgear (GIS) satu fasa dan GIS tiga fasa.
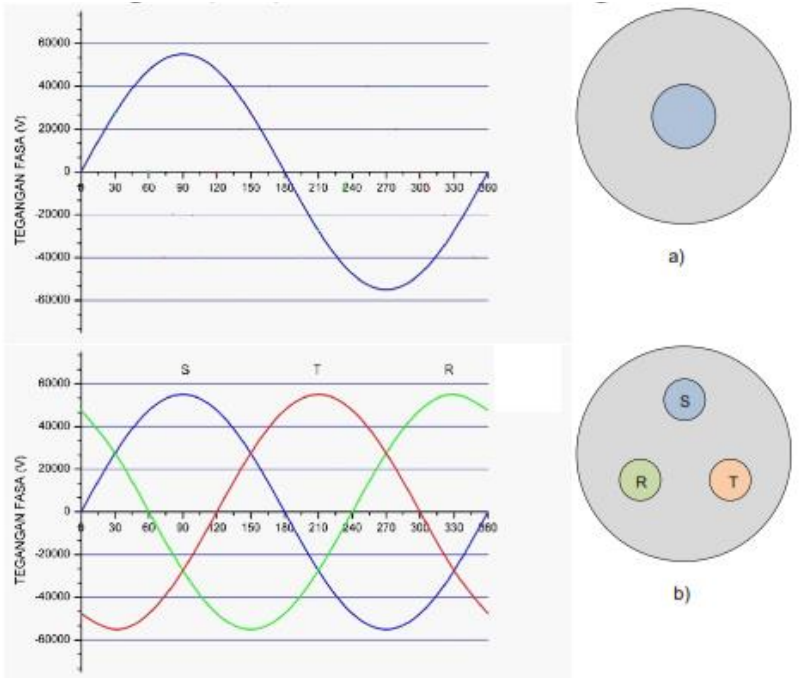

a)

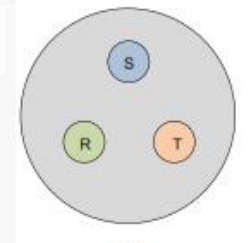

b)

Gambar 2. Konfigurasi dan tegangan kerja peralatan 1 fasa dan 3 fasa.

Meskipun keandalan Gas Insulated Switchgear (GIS) telah terbukti selama lebih dari empat puluh tahun, beberapa kegagalan telah dilaporkan. CIGRE melaporkan 25/23 -01 menyebutkan kegagalan disebabkan oleh partikel dan benda asing merupakan $20 \%$ dari total distribusi jenis cacat dalam kegagalan GIS. Kehadiran partikel asing tersebut mengakibatkan terjadi peningkatan konsentrasi medan listrik dalam tangki GIS yang dapat mempengaruhi media isolasi dan dapat menyebabkan kerusakan $[6,11,13,15,16]$.

Perhitungan medan listrik pada GIS 3 fasa susunan equilateral yang terdapat partikel asing pada tangkinya membantu memahami fenomena yang akan terjadi pada peralatan 3 fasa tersebut.
Pada penelitian ini akan dilakukan perhitungan medan listrik pada GIS equilateral 3 fasa yang bertujuan untuk menganalisa pengaruh keberadaan partikel asing dan letak partikel terhadap distribusi medan listrik dalam tangki GIS, besar nilai medan listrik pada beberapa titik tinjau dalam tangki GIS dan bentuk lokus medan listrik pada beberapa titik dalam tangki GIS dengan posisi partikel dalam tangki GIS yang bervariasi.

\section{Metode Elemen Hingga}

Metode Elemen Hingga (Finite Element Method) adalah metode numerik yang digunakan untuk menyelesaikan permasalahan matematis dari suatu gejala fisika. Metode ini dapat menghasilkan solusi dari persamaan diferensial parsial dan persamaan integral. Metode elemen hingga dapat menangani beberpa masalah meliputi (Burnett, 1987):

a. Berbagai masalah matematika dan fisika meliputi persamaan kalkulus seperti differensial, integral, dan variasi persamaanpersamaan.

b. Masalah boundary value (seperti masalah steady-state), masalah eigen (fenomena resonansi dan stabilitas), dan masalah initial value (difusi, vibrasi, dan propagansi gelombang).

c. Sifat fisika seperti densitas, permiabialitas, dan konduktivitas yang bervariasi pada sistem.

d. Masalah dapat berupa linear dan non-linear.

Dalam bidang teknik, tipe masalah yang dapat diselesaikan dengan metode elemen hingga terbagi dalam dua kelompok, yaitu kelompok analisis struktur dan kelompok analisis nonstruktur. Untuk kasus medan listrik, analisis yang digunakan merupakan analisa non-struktur. Metode ini bagus digunakan pada daerah yang memiliki batas. Seperti terlihat pada Gambar 3, sebuah penampang 2 dimensi dari sebuah konduktor dalam tangki isolasi gas. Intensitas medan listrik akan dihitung memakai metode elemen hingga.

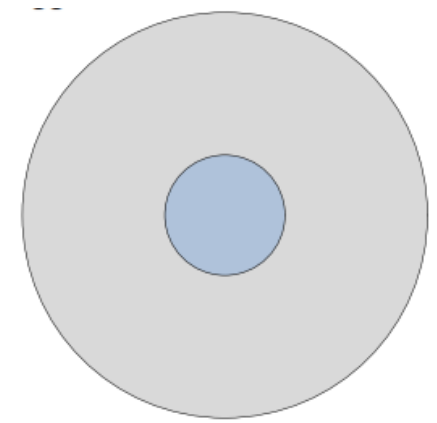

Gambar 3. Penampang 2 dimensi sebuah konduktor dalam tangki isolasi 
Fungsi medan elektrostatik merupakan energi potensial yang tersimpan pada suatu daerah permukaan pada bidang 2 dimensi, fungsi potensial listriknya dapat ditulis menjadi:

$\frac{W_{\Delta V}}{\Delta \mathrm{z}}=\frac{1}{2} \varepsilon \int_{\Delta S}\left(\left(\frac{\mathrm{d} \varphi}{\mathrm{dx}}\right)^{2}+\left(\frac{\mathrm{d} \varphi}{\mathrm{dy}}\right)^{2}\right) d S$

Pemecahan masalah medan listrik dengan finite element method dapat dilakukan dengan 4 langkah dasar yaitu [13]:

a. Diskretisasi,

membagi domain yang akan ditinjau menjadi elemen-elemen berhingga (finite element) berbentuk segitiga, seperti terlihat pada Gambar 4. Medan listrik pada suatu domain/elemen dapat ditentukan bila diketahui besarnya potensial listrik pada domain/elemen tersebut dan potensial listrik pada domain/elemen sekitarnya. Potensial listrik suatu elemen satu dengan elemen lain saling mempengaruhi dalam menentukan besarnya medan listrik.

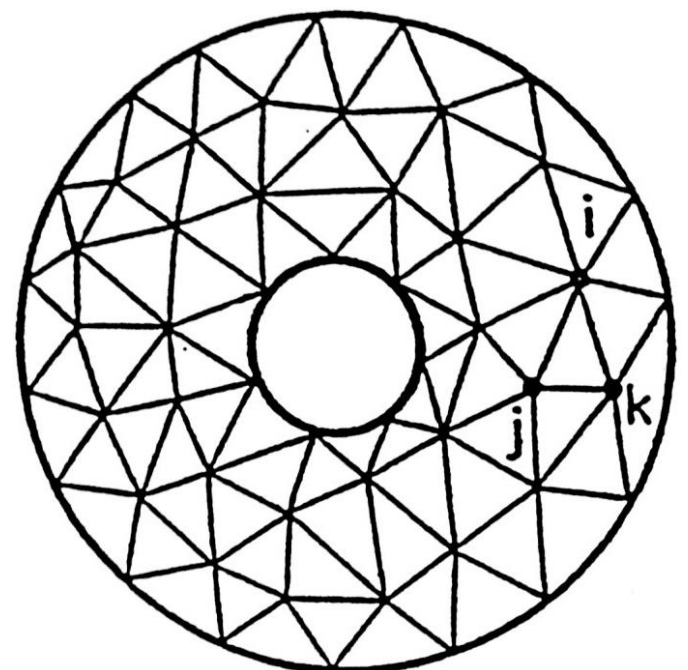

Gambar 4. Diskretisasi daerah medan pada bidang 2 dimensi.

b. Fungsi pendekatan $\varphi_{\Delta \mathrm{S}}(\mathrm{x}, \mathrm{y})$,

pendekatan sederhana sebagai sebuah fungsi potensial dapat ditulis dengan persamaan:

$\varphi_{\Delta S}(x, y)=C_{1}+C_{2} x+C_{3} y$

Pada simpul $\mathrm{i}, \mathrm{j}$, dan $\mathrm{k}$ dengan koordinat $\mathrm{x}_{\mathrm{i}} \mathrm{y}_{\mathrm{i}}$, $\mathrm{x}_{\mathrm{j}} \mathrm{y}_{\mathrm{j}}, \mathrm{x}_{\mathrm{k}} \mathrm{y}_{\mathrm{k}}$ dan koefisien $\mathrm{C} 1, \mathrm{C} 2, \mathrm{C} 3$ dapat ditulis dalam 3 persamaan yang merupakan titik potensial $\varphi_{\mathrm{i}}, \varphi_{\mathrm{j}}, \varphi_{\mathrm{k}}$.

$$
\varphi_{\mathrm{i}}\left(x_{i}, y_{i}\right)=C_{1}+C_{2} x_{i}+C_{3} y_{i}
$$

$$
\begin{aligned}
\varphi_{\mathrm{j}}\left(x_{j}, y_{j}\right) & =C_{1}+C_{2} x_{j}+C_{3} y_{j} \\
\varphi_{\mathrm{k}}\left(x_{k}, y_{k}\right) & =C_{1}+C_{2} x_{k}+C_{3} y_{k}
\end{aligned}
$$

Kemudian dibuat persamaan pendekatan kedua yang memperkirakan potensial di dalam elemen:

$$
\varphi_{\Delta \mathrm{S}}(\mathrm{x}, \mathrm{y})=N_{\mathrm{i}}(\mathrm{x}, \mathrm{y}) \varphi_{\mathrm{i}}+N_{\mathrm{j}}(\mathrm{x}, \mathrm{y}) \varphi_{\mathrm{j}}+N_{\mathrm{k}}(\mathrm{x}, \mathrm{y}) \varphi_{\mathrm{k}}
$$

Fungsi $\mathrm{Ni}, \mathrm{Nj}, \mathrm{Nk}$ disebut persamaan interpolasi pada sebuah elemen. Pendekatan linear elemen tersebut dihitung dengan;

$$
\begin{aligned}
& N_{i}(x, y)=\frac{1}{2 \Delta S}\left(\left(x_{j} y_{k}-x_{k} y_{j}\right)+\left(y_{j}-y_{k}\right) x+\right. \\
& \left(x_{k}-x_{j}\right) y
\end{aligned}
$$

c. Membangun matrik elemen,

Pada bagian ini, pertama dilakukan tturunan parsial dari potensial hasil dari fungsi pendekatan elemen $\varphi_{\Delta \mathrm{S}}(\mathrm{x}, \mathrm{y})$ terhadap $\mathrm{x}$ dan $\mathrm{y}$, sebagai berikut:

$\frac{\partial \varphi_{\Delta \mathrm{S}}}{\partial y}=\frac{\partial \mathrm{N}_{\mathrm{i}}(\mathrm{x}, \mathrm{y})}{\partial y} \varphi_{i}+\frac{\partial \mathrm{N}_{\mathrm{j}}(\mathrm{x}, \mathrm{y})}{\partial y} \varphi_{j}+\frac{\partial \mathrm{N}_{\mathrm{k}}(\mathrm{x}, \mathrm{y})}{\partial y} \varphi_{k}$

Kemudian subsitusi persamaan 6 ke persamaan fungsi sebuah elemen $\Delta \mathrm{S}$.

$\frac{W_{\Delta V}}{\Delta \mathrm{z}}=\mathrm{X}_{\Delta \mathrm{S}}=\frac{1}{2} \varepsilon \int_{\Delta S}\left(\left(\frac{\mathrm{d} \varphi}{\mathrm{dx}}\right)^{2}+\left(\frac{\mathrm{d} \varphi}{\mathrm{dy}}\right)^{2}\right) d S$

Kemudian dibentuk persamaan fungsi simpulsimpul pada sebuah elemen "ijk",

$\mathrm{X}_{\Delta \mathrm{S}}=\mathrm{f}\left(\varphi_{i}, \varphi_{j}, \varphi_{k}\right)$

Persamaan 8 diturunkan terhadap potensial, $\frac{\partial \mathrm{X}_{\Delta \mathrm{S}}}{\partial \varphi_{\Delta \mathrm{S}}} \triangleq 0$ atau kalau dipecah menjadi:

$\frac{\partial \mathrm{X}_{\Delta \mathrm{S}}}{\partial \varphi_{\mathrm{i}}} \triangleq 0 ; \frac{\partial \mathrm{X}_{\Delta \mathrm{S}}}{\partial \varphi_{\mathrm{j}}} \triangleq 0 ; \frac{\partial \mathrm{X}_{\Delta \mathrm{S}}}{\partial \varphi_{\mathrm{k}}} \triangleq 0$

Turunan parsial dari 3 buah persamaan potensial $\varphi_{i}, \varphi_{j}, \varphi_{k}$ Setelah mendapatkan persamaan pendekatan pada elemen, maka dapat dibentuk suatu matrik elemen:

$$
\left[\begin{array}{ccc}
p_{i i} & p_{i j} & p_{i k} \\
p_{j i} & p_{\mathrm{jj}} & p_{j k} \\
p_{k i} & p_{k j} & p_{k k}
\end{array}\right]\left[\begin{array}{c}
\varphi_{\mathrm{i}} \\
\varphi_{\mathrm{j}} \\
\varphi_{\mathrm{k}}
\end{array}\right]=0
$$


d. Membangun matrik sistem,

yakni merangkaikan persamaan matriks elemen $\mathrm{n}$ untuk setiap simpul menjadi matriks sistem. Perlu diingat, energi total pada daerah medan listrik merupakan penjumlahan energi tiap elemen hasil diskretisasi, fungsi sistem $\mathrm{X}=\mathrm{f}(\varphi(\mathrm{x}, \mathrm{y}))$ adalah total fungsi elemen $\mathrm{X}_{\Delta S}=\mathrm{f}\left(\varphi_{\Delta S}(\mathrm{x}, \mathrm{y})\right)$. Turunan parsial dari fungsi sistem terhadap semua potensial simpul,

$\frac{\partial \mathrm{W}}{\partial \varphi} \triangleq 0$

Persamaan sistem linear untuk $\mathrm{n}$ jumlah potensial simpul dapat ditulis:

$$
[\mathrm{P}][\varphi]=0
$$

Koefisien matrik sistem didapatkan dengan menjumlahkan semua koefisien matrik elemen yang terkait. Setiap baris dari matrik sistem merupakan sebuah simpul elemen dan terhubung ke semua simpul elemen dari penggabungan elemen,

$\mathrm{P}_{\mathrm{mn}}=\sum \mathrm{p}_{\mathrm{mn}}$

Sebagai contoh pada Gambar 5, untuk simpul 10 , elemen diagonal untuk matrik sistem $\mathrm{P}_{10,10}$ didapatkan dari,

$$
\begin{aligned}
& \mathrm{P}_{10,10}=\mathrm{p}_{10,10(1)}+\mathrm{p}_{10,10(2)}+\mathrm{p}_{10,10(3)}+\cdots+ \\
& \mathrm{p}_{10,10(6)}
\end{aligned}
$$

Untuk selain elemen dioagonal dari matrik sistem, seperti $\mathrm{P}_{10,12}$ didapat dengan,

$$
\mathrm{P}_{10,12}=\mathrm{p}_{10,12(2)}+\mathrm{p}_{10,12(3)}
$$

e. Menentukan kondisi batas,

menyelesaikan persamaan matriks elemen untuk memperoleh nilai-nilai pada setiap simpul dengan menentukan batas kondisi untuk penyelesaian persamaan sistem linear,

$$
\widetilde{[P}][\widetilde{\varphi}]=[\mathrm{P}]_{\text {boundary }}[\varphi]_{\text {boundary }}
$$

Nilai potensial untuk semua simpul elemen pada daerah bermedan diselesaikan dengan,

$$
[\widetilde{\varphi}]=[\widetilde{\mathrm{P}}]^{-1}[\mathrm{P}]_{\text {boundary }}[\varphi]_{\text {boundary }}
$$

Pada penyelesaian masalah medan dalam perangkat lunak, persamaan sistem linear diselesaikan dengan iterasi, bukan dengan matrik invers. Dengan mengevaluasi potensial simpul, fungsi potensial $\varphi_{\Delta S}(\mathrm{x} . \mathrm{y})$ dan kuat medan listrik $\mathrm{E}=$ $-\operatorname{grad} \varphi$ dapat diketahui.
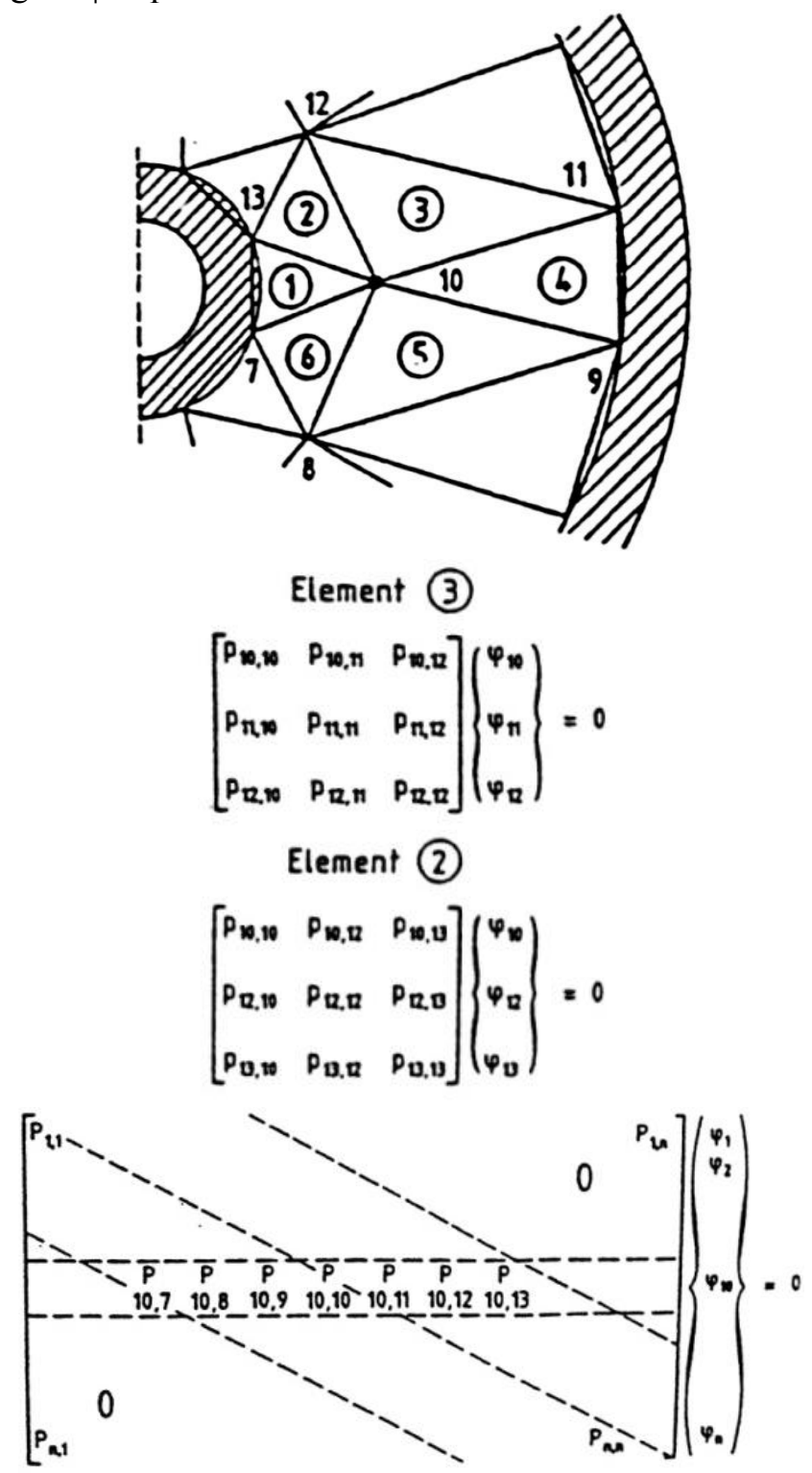

Gambar 5. Notasi simpul dan elemen dalam pembentukan matrik sistem

\section{Metodologi Penelitian}

\subsection{Model Peralatan Listrik Tegangan Tinggi GIS tiga Fasa}

Peralatan listrik tegangan tinggi yang akan dianalis pada riset ini adalah busbar berisolasi gas tiga fasa/ gas insulated switchgear (GIS). Model yang disederhanakan dari GIS tiga fasa digunakan pada riset ini. Model ini terdiri atas suatu model 
tangki dengan diameter $150 \mathrm{~mm}$, panjang $300 \mathrm{~mm}$, ketebalan $2 \mathrm{~mm}$ dan konduktor tiga fasa dengan diameter $25 \mathrm{~mm}$, seperti terlihat pada Gambar 6 .

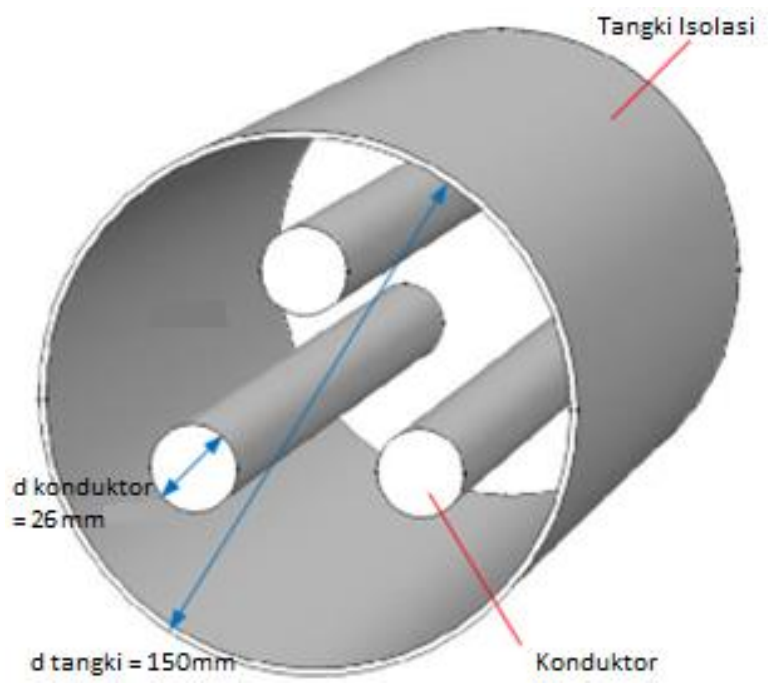

Gambar 6. Model busbar berisolasi gas SF6 pada GIS equilateral 3 fasa

Susunan elektroda konduktor dan tangki diatur secara equilateral, dimana konduktor tersusun dalam bentuk segitiga sama-sisi. Pada riset ini, perhitungan dan analisa medan lstrik dilakukan pada bidang 2 dimensi. Tegangan pada konduktorkonduktor sebesar $55 \mathrm{kV}$ yang berbeda fasa pada masing-masingnya sebesar $120^{\circ}$. Susunan, dimensi model, dan tegangan pada masing-masing konduktor ditunjukkan pada Gambar 7.
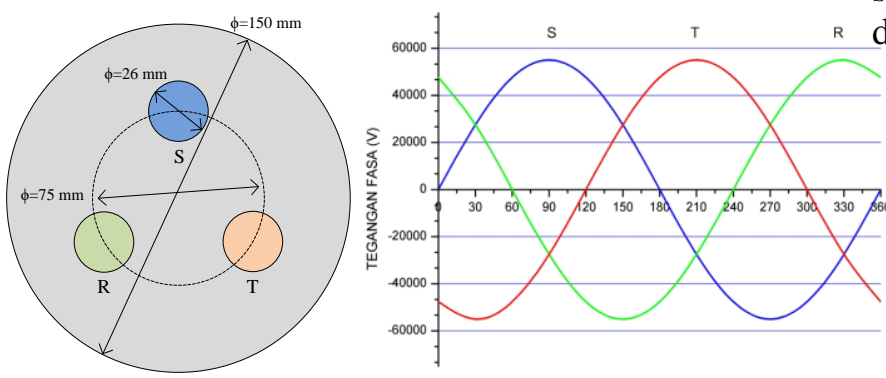

Gambar 7. Deskripsi model GIS tiga fasa yang disederhanakan dan tegangan masingmasing konduktor.

\subsection{Asumsi Dasar Pemodelan Peralatan Listrik GIS Equilateral 3 Fasa}

Peralatan GIS 3 fasa telah banyak dipakai pada sistem penyaluran tenaga listrik. Beberapa peralatan GIS 3 fasa yang difabrifikasi memiliki rating tegangan yang bervariasi. Rating tegangan maksimum untuk GIS 3 fasa yang banyak dipakai pada sistem tenaga sebesar $275 \mathrm{kV}$. Pada bagian busbar peralatan GIS 3 fasa dengan rating tegangan $275 \mathrm{kV}$, memiliki tangki isolasi dengan diameter $750 \mathrm{~mm}$ dengan diameter konduktor $125 \mathrm{~mm}$. Gas SF6 sebagai medium isolasi memiliki kekuatan dielektrik $89 \mathrm{kV} / \mathrm{cm}$. Pada pemakaian GIS di lapangan, tekanan gas SF6 bervariasi sesuai dengan kebutuhan. Tekanan gas SF6 mempengaruhi kekuatan dielektrik gas. Gas SF6 memiliki kekuatan dielektrik sebesar $70-80 \mathrm{kV} / \mathrm{cm}$ per $\mathrm{MPa}$ [8].

Pada model GIS yang akan diteliti, dimensi dan ukuran konduktor yang digunakan diperkecil dari kondisi GIS yang asli. Perbandingan ukuran tangki dan konduktor antara model GIS 3 fasa dengan GIS 3 fasa asli adalah $1: 5$. Tekanan gas SF6 yang dipakai pada model GIS 3 fasa ini sebesar 1.1 MPa. Sehingga pada pemodelan ini, kekuatan dielektrik gas SF6 adalah $89 \mathrm{kV} / \mathrm{cm}$. Besar tegangan AC yang digunakan dalam pemodelan seperlima dari tegangan pada GIS asli, yaitu sebesar $55 \mathrm{kV}$. Penentuan ukuran tangki, ukuran konduktor, tekanan gas SF6, dan tegangan yang diaplikasikan disesuaikan dengan penelitian terdahulu $[1,2,3,4,8]$.

\subsection{Perhitungan dan Analisa Medan Listrik}

Pada penelitian ini medan listrik dalam isolasi peralatan tegangan tinggi tiga fasa ditentukan dengan simulasi metode elemen hingga, pada lingkaran di antara fasa-fasa dan tangki, sepanjang garis vertikal mulai dari bagian bawah tangki, titik tengah pada garis antara 2 konduktor fasa dan pada sekitar konduktor. Perhitungan medan listrik yang dilakukan adalah pada bidang dua dimensi.

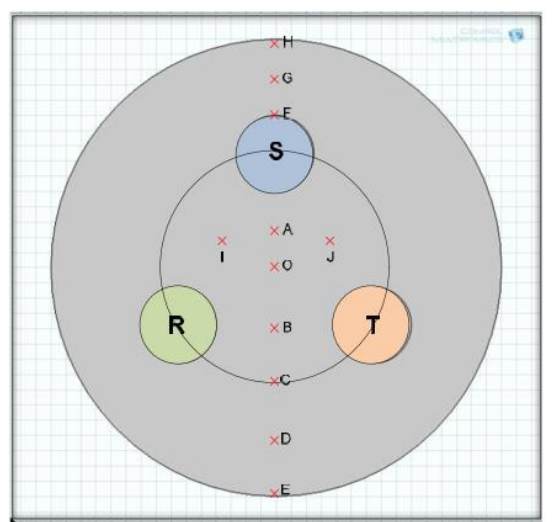

Gambar 8. Posisi titik tinjau medan listrik dalam model GIS 3 fasa susunan equilateral

\subsection{Pengaruh Kehadiran Partikel Asing}

Kehadiran partikel asing merupakan penyebab utama kegagalan pada GIS. Penelitian pada GIS satu fasa telah banyak dilakukan. Karakteristik 
medan listrik tiga fasa terhadap kehadiran partikel asing akan diteliti pada studi ini. Partikel asing pada GIS dapat berupa: tonjolan pada konduktor, tonjolan pada selubung, partikel bebas pada selubung, partikel yang mengambang pada isolasi, elektroda mengambang, partikel pada spacer. Pada studi akan dianalisis pengaruh partikel dalam tangki GIS susunan equilateral yang terletak pada selubung dalam tangki, partikel mengambang, dan partikel pada salah satu konduktor.

Pada beberapa kasus dalam GIS 3 fasa, partikel asing berukuran kecil di dalam tangki mengalami perpindahan posisi. Partikel bergerak ini mulai mengalami perubahan posisi dalam selang waktu diatas 1 detik $[6,17,18]$. Pada riset ini, partikel disumsikan tetap berada pada posisinya selama satu siklus tegangan (0.02 detik). Pemberian nama partikel asing berdasarkan posisinya di dalam tangki GIS dapat dilihat pada Gambar 9. Medan listrik akan dilihat pada beberapa titik tinjau seperti pada Gambar 8.

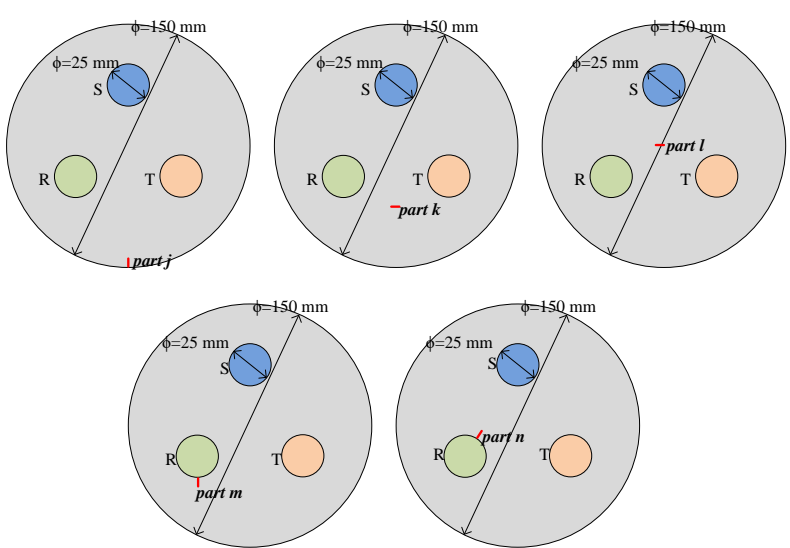

Gambar 9. Posisi partikel dalam model GIS 3 fasa susunan equilateral

Tujuan dari perhitungan medan listrik dengan memvariasikan letak partikel asing pada tangki GIS equilateral ini adalah :

1. Melihat pengaruh keberadaan partikel asing dan letak partikel terhadap distribusi medan listrik dalam tangki GIS equilateral dengan memvariasikan letak partikel dalam tangki.

2. Melihat pengaruh keberadaan partikel asing dan letak partikel terhadap besar medan listrik pada beberapa titik dengan memvariasikan letak partikel.

3. Melihat pengaruh keberadaan partikel asing dan letak partikel terhadap lokus medan listrik pada beberapa titik dalam tangki GIS equilateral dengan memvariasikan letak partikel.

\section{Hasil dan Pembahasan}

\subsection{Distribusi medan listrik dalam tangki GIS equilateral 3 fasa dengan keberadaan partikel asing}

Setelah melakukan perhitungan, perangkat lunak menggunakan metode FEM, didapatkan distribusi medan listrik di dalam tangki GIS equilateral dan besar medan listrik di beberapa titik dalam tangki GIS equilateral 3 fasa dengan mensimulasikan variasi letak partikel. Pada Gambar 10 dapat dilihat distribusi medan listrik dalam tangki GIS equilateral tanpa partikel dan eksistansi partikel dengan memvariasikan letak partikel tersebut, perhitungan dilakukan dalam satu siklus tegangan sinusoidal.

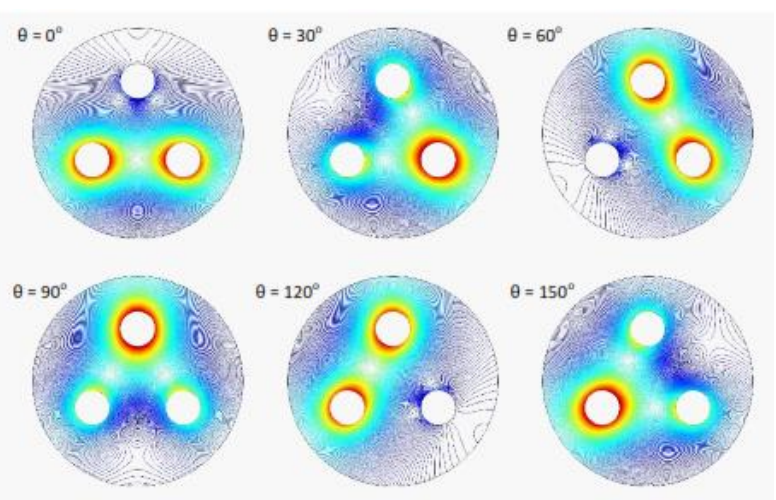

Gambar 10. Distribusi medan listrik dalam tangki GIS equilateral tanpa partikel

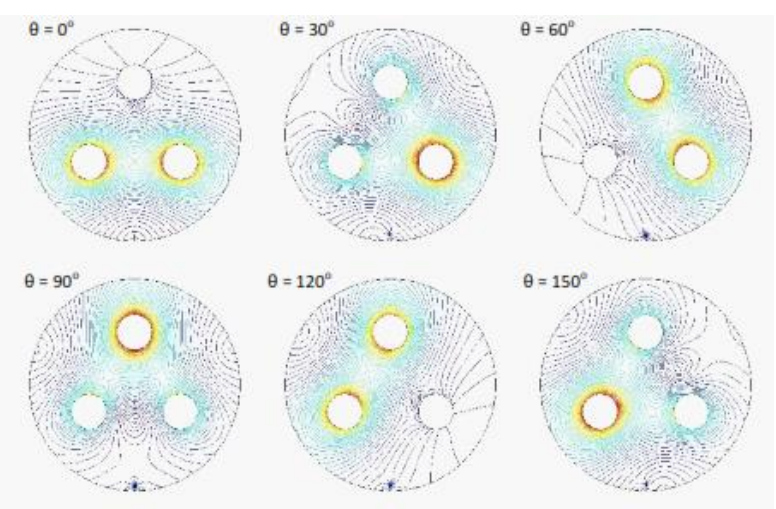

Gambar 11. Distribusi medan listrik dalam tangki GIS equilateral dengan keberadaan partikel j 


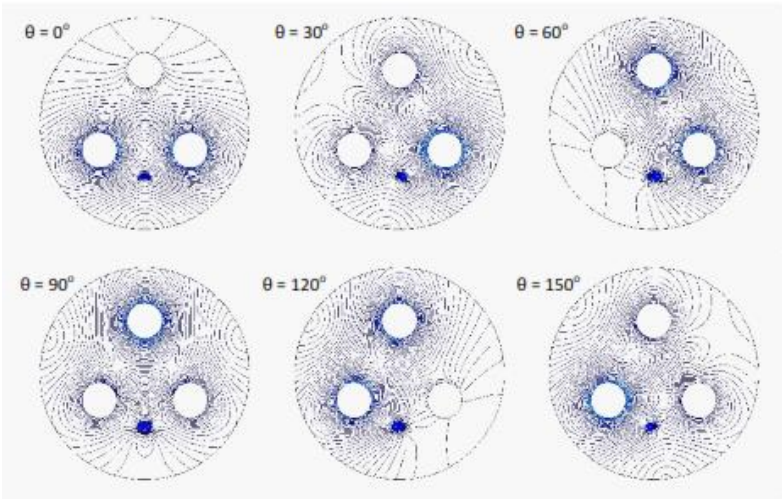

Gambar 12. Distribusi medan listrik dalam tangki GIS equilateral dengan keberadaan partikel k
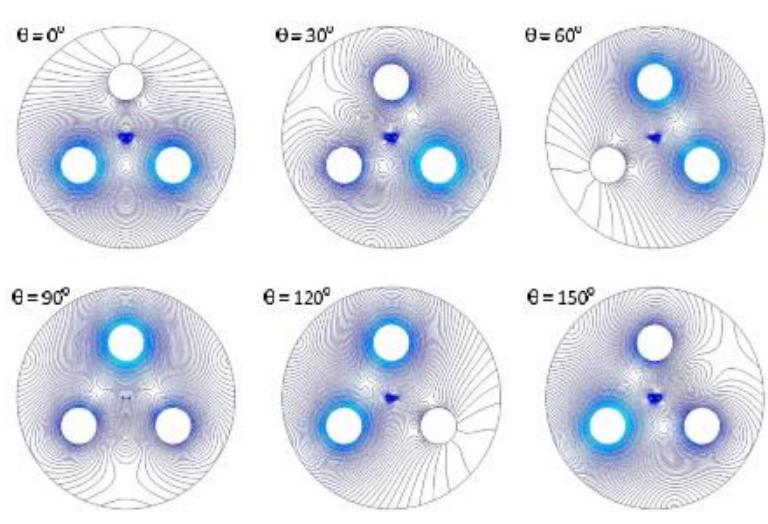

Gambar 13. Distribusi medan listrik dalam tangki GIS equilateral dengan keberadaan partikel 1

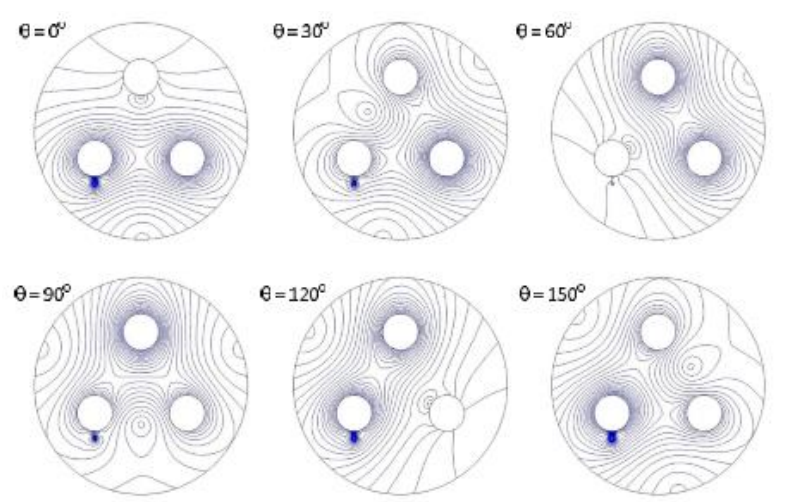

Gambar 14. Distribusi medan listrik dalam tangki GIS equilateral dengan keberadaan partikel $\mathrm{m}$

Gambar 11, 12, 13, 14 dan 15 merupakan distribusi medan listrik dalam tangki GIS dengan keberadaan partikel asing menyebabkan perubahan distribusi medan listrik dalam tangki.
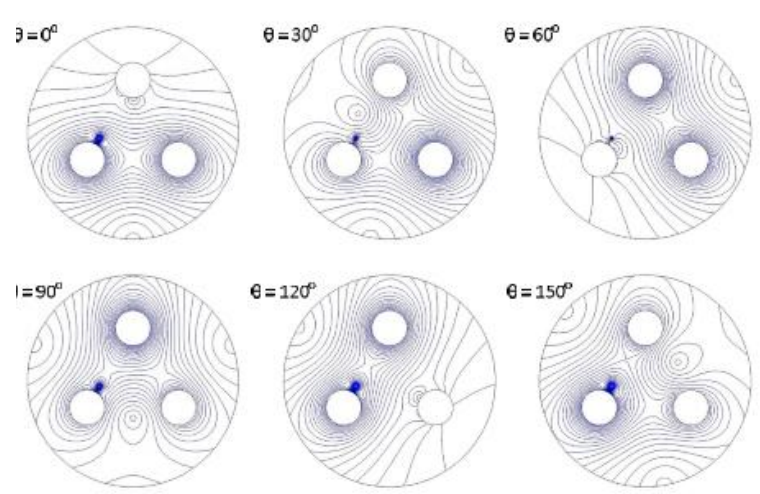

Gambar 15. Distribusi medan listrik dalam tangki GIS equilateral dengan keberadaan partikel $n$

Keberadaan partikel menghasilkan intensitas medan listrik tertinggi berada pada ujung-ujung partikel. Hal ini disebabkan oleh keberadaan partikel yang menyebabkan medanlistrik dalam tangki GIS equilateral menjadi tidak normal. Semakin tingginya intensitas medan listrik tersebut meningkatkan kemungkinan terjadinya peluahan di dalam tangki GIS equilateral.

\subsection{Medan listrik pada beberapa titik tangki GIS equilateral 3 fasa dengan keberadaan partikel asing.}

Setelah melakukan perhitungan dapat diketahui besar medan listrik pada beberapa titik dalam tangki GIS equilateral. Dari hasil perhitungan ini kita dapat membandingkan pengaruh letak partikel terhadap besar medan listrik pada beberapa titik.

Tabel 1. Besar medan listrik di titik O pusat GIS dengan memvariasikan letak partikel

\begin{tabular}{|c|c|c|c|c|c|c|}
\hline $\begin{array}{c}\text { Sudut } \\
\text { fasa } \\
(\theta)^{\mathrm{o}}\end{array}$ & \multicolumn{5}{|c|}{ Besar medan listrik (kV/cm) di titik dengan } \\
\hline 0 & 13.3 & 13.3 & 13.3 & 0.0 & 13.3 & 13.8 \\
\cline { 2 - 7 } 30 & 13.3 & 13.3 & 13.1 & 0.0 & 13.3 & 13.5 \\
60 & 13.3 & 13.3 & 12.9 & 0.0 & 13.3 & 13.2 \\
90 & 13.3 & 13.3 & 12.8 & 0.0 & 13.3 & 13.3 \\
120 & 13.3 & 13.3 & 12.9 & 0.0 & 13.3 & 13.6 \\
150 & 13.3 & 13.3 & 13.1 & 0.0 & 13.3 & 13.9 \\
180 & 13.3 & 13.3 & 13.3 & 0.0 & 13.3 & 13.8 \\
210 & 13.3 & 13.3 & 13.1 & 0.0 & 13.3 & 13.5 \\
240 & 13.3 & 13.3 & 12.9 & 0.0 & 13.3 & 13.2 \\
270 & 13.3 & 13.3 & 12.8 & 0.0 & 13.3 & 13.3 \\
300 & 13.3 & 13.3 & 12.9 & 0.0 & 13.3 & 13.6 \\
330 & 13.3 & 13.3 & 13.1 & 0.0 & 13.3 & 13.9 \\
360 & 13.3 & 13.3 & 13.3 & 0.0 & 13.3 & 13.8 \\
\hline
\end{tabular}




\subsubsection{Medan listrik di titik $O$ dengan keberadaan partikel asing}

Titik O terletak pada pusat tangki GIS yang berjarak sama ke permukaan konduktor $\mathrm{S}$, konduktor R, dan konduktor T, sejauh $25 \mathrm{~mm}$, seperti terlihat pada Gambar 7. Medan listrik pada titik O pada kondisi normal memiliki besar yang sama selama satu siklus tegangan sinusoidal. Pada Tabel 1 dapat dilihat besar medan listrik di titik $\mathrm{O}$ yang disebabkan keberadaan partikel dengan posisi yang berbeda-beda.

Pada Gambar 16 dapat dilihat besar medan listrik di titik $\mathrm{O}$ dengan variasi letak partikel dalam tangki GIS equilateral. Terlihat keberadaan partikel menyebabkan perubahan medan listrik pada titik pusat tangki ini dimana pada kondisi tidak berpartikel medan listriknya tetap. Keberadaan partikel $\mathrm{m}$ dan partikel $\mathrm{n}$ menyebabkan medan listrik di titik $\mathrm{O}$ mengalami pergeseran fasa dari medan listrik kondisi normal.

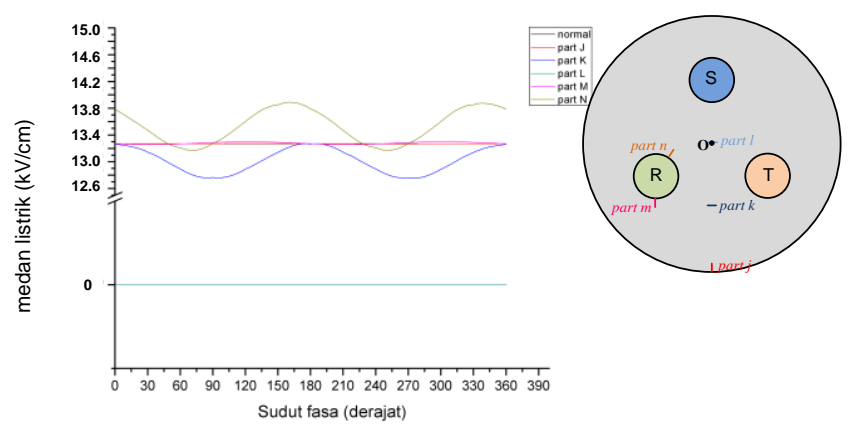

Gambar 16. Medan listrik di titik O dengan keberadaan partikel asing pada posisi yang berbeda-beda

\subsubsection{Medan listrik di titik A dengan keberadaan partikel asing}

\begin{tabular}{|c|c|c|c|c|c|c|}
\hline sat & \multicolumn{6}{|c|}{$\begin{array}{c}\text { Besar medan listrik }(\mathrm{kV} / \mathrm{cm}) \text { di titik dengan } \\
\text { variasi letak partikel }\end{array}$} \\
\hline$(\theta)^{\mathrm{o}}$ & Normal & Partikel j & jPartikel k & Partikel l & Partikel m & Partikel n \\
\hline 0 & 7.5 & 7.5 & 7.5 & 7.2 & 7.5 & 7.5 \\
\hline 30 & 12.0 & 12.0 & 11.9 & 11.9 & 12.0 & 12.0 \\
\hline 60 & 18.0 & 18.0 & 17.7 & 17.9 & 18.0 & 18.0 \\
\hline 90 & 20.3 & 20.3 & 20.0 & 20.3 & 20.3 & 20.3 \\
\hline 120 & 18.0 & 18.0 & 17.7 & 17.9 & 18.0 & 18.0 \\
\hline 50 & 12.0 & 12.0 & 11.9 & 11.9 & 12.0 & 12.0 \\
\hline 30 & 7.5 & 7.5 & 7.5 & 7.2 & 7.5 & 7.5 \\
\hline & 12.0 & 12.0 & 11.9 & 11.9 & 12.0 & 12.0 \\
\hline & 18.0 & 18.0 & 17.7 & 17.9 & 18.0 & 18.0 \\
\hline 70 & 20.3 & 20.3 & 20.0 & 20.3 & 20.3 & 20.3 \\
\hline 00 & 18.0 & 18.0 & 17.7 & 17.9 & 18.0 & 18.0 \\
\hline 30 & 12.0 & 12.0 & 11.9 & 11.9 & 12.0 & 12.0 \\
\hline 60 & 7.5 & 7.5 & 7.5 & 7.2 & 7.5 & 7.5 \\
\hline
\end{tabular}

Titik A terletak pada pertengahan jarak permukaan konduktor $\mathrm{S}$ yang menghadap pusat dengan titik pusat tangki GIS equilateral, berjarak sejauh $12.5 \mathrm{~mm}$ dari pusat tangki, seperti terlihat pada Gambar 17. Pada Tabel 2 dapat dilihat besar medan listrik di titik A pada perhitungan medan listrik dengan memvariasikan letak keberadaan partikel.

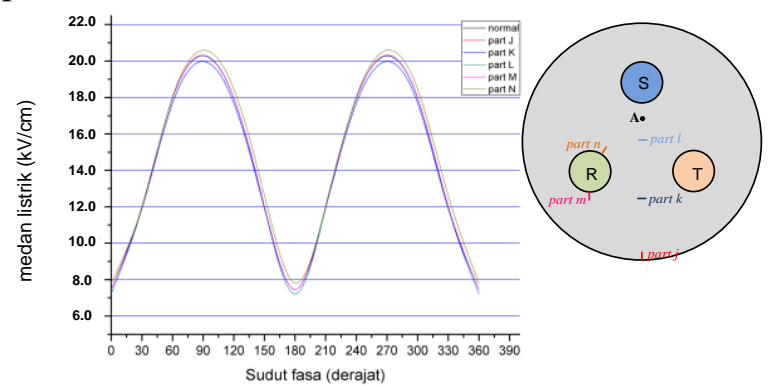

Gambar 17. Medan listrik di titik A dengan keberadaan partikel asing pada posisi yang berbeda-beda

\subsubsection{Medan listrik di titik $B$ dengan keberadaan partikel asing}

Tabel 3. Besar medan listrik di titik B pusat GIS dengan memvariasikan letak partikel

\begin{tabular}{|c|c|c|c|c|c|c|}
\hline \multirow{2}{*}{$\begin{array}{c}\text { Sudut } \\
\text { fasa } \\
(\theta)^{\circ}\end{array}$} & \multicolumn{5}{|c|}{ Besar medan listrik (kV/cm) di titik dengan } \\
\cline { 2 - 7 } & Normal & Partikel j] & Partikel k & Partikel 1 & Partikel m & Partikel n \\
\hline 0 & 19.4 & 19.4 & 19.3 & 19.3 & 19.5 & 19.4 \\
30 & 16.9 & 16.9 & 16.8 & 16.8 & 16.9 & 16.9 \\
60 & 10.2 & 10.1 & 9.7 & 10.1 & 10.2 & 10.2 \\
90 & 3.5 & 3.5 & 1.4 & 3.5 & 3.6 & 3.5 \\
120 & 10.2 & 10.2 & 9.7 & 10.1 & 10.2 & 10.2 \\
150 & 16.9 & 16.9 & 16.7 & 16.8 & 17.0 & 16.9 \\
180 & 19.4 & 19.4 & 19.3 & 19.3 & 19.5 & 19.4 \\
210 & 16.9 & 16.9 & 16.8 & 16.8 & 16.9 & 16.9 \\
240 & 10.2 & 10.1 & 9.7 & 10.1 & 10.2 & 10.2 \\
270 & 3.5 & 3.5 & 1.4 & 3.5 & 3.6 & 3.5 \\
300 & 10.2 & 10.2 & 9.7 & 10.1 & 10.2 & 10.2 \\
330 & 16.9 & 16.9 & 16.7 & 16.8 & 17.0 & 16.9 \\
360 & 19.4 & 19.4 & 19.3 & 19.3 & 19.5 & 19.4 \\
\hline
\end{tabular}

Titik B terletak pada pertengahan antara konduktor R dan konduktor T berjarak $18.75 \mathrm{~mm}$ dari pusat tangki, seperti terlihat pada Gambar 18. Pada Tabel 3 dapat dilihat besar medan listrik di titik B yang disebabkan oleh variasi letak keberadaan partikel dalam tangki GIS. Pada Gambar 18 dapat dilihat besar medan listrik di titik B dengan variasi letak partikel dalam tangki GIS equilateral. Keberadaan partikel $\mathrm{k}$ menyebabkan perubahan medan listrik minimum pada titik B ini. 


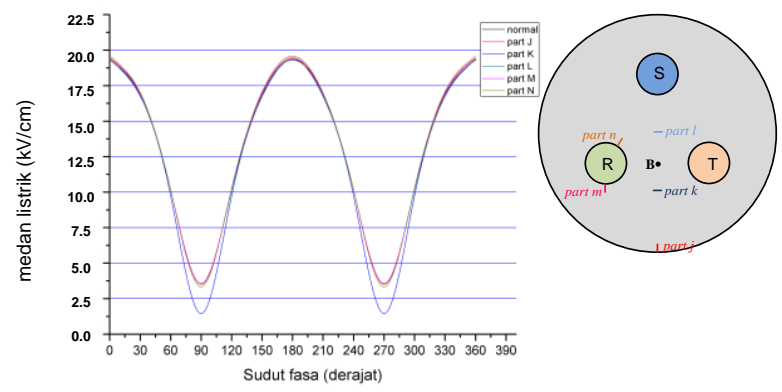

Gambar 18. Medan listrik di titik B dengan keberadaan partikel asing pada posisi yang berbeda-beda

\subsubsection{Medan listrik di titik $\mathrm{C}$ dengan keberadaan partikel asing}

Tabel 4. Besar medan listrik di titik C pusat GIS dengan memvariasikan letak partikel

\begin{tabular}{|c|c|c|c|c|c|c|}
\hline $\begin{array}{c}\text { Sudut } \\
\text { fasa } \\
(\theta)^{\circ}\end{array}$ & \multicolumn{5}{|c|}{ Besar medan listrik (kV/cm) di titik dengan } \\
\cline { 2 - 7 } variasi letak partikel \\
\hline 0 & 12.8 & 12.8 & 0.0 & 12.8 & 13.0 & 12.8 \\
30 & 11.2 & 11.2 & 0.0 & 11.2 & 11.3 & 11.2 \\
60 & 6.9 & 6.9 & 0.0 & 6.9 & 7.0 & 6.9 \\
90 & 3.1 & 3.2 & 0.0 & 3.1 & 3.1 & 3.1 \\
120 & 6.9 & 7.0 & 0.0 & 6.9 & 7.1 & 6.9 \\
150 & 11.2 & 11.2 & 0.0 & 11.2 & 11.4 & 11.2 \\
180 & 12.8 & 12.8 & 0.0 & 12.8 & 13.0 & 12.8 \\
210 & 11.2 & 11.2 & 0.0 & 11.2 & 11.3 & 11.2 \\
240 & 6.9 & 6.9 & 0.0 & 6.9 & 7.0 & 6.9 \\
270 & 3.1 & 3.2 & 0.0 & 3.1 & 3.1 & 3.1 \\
300 & 6.9 & 7.0 & 0.0 & 6.9 & 7.1 & 6.9 \\
330 & 11.2 & 11.2 & 0.0 & 11.2 & 11.4 & 11.2 \\
360 & 12.8 & 12.8 & 0.0 & 12.8 & 13.0 & 12.8 \\
\hline
\end{tabular}

Titik C terletak pada tangki GIS yang berjarak $37.5 \mathrm{~mm}$ pusat tangki dan dalam satu garis vertikal dengan konduktor S, seperti terlihat pada Gambar 19. Pada Tabel 4 dapat dilihat besar medan listrik di titik $\mathrm{C}$ dengan variasi letak partikel.

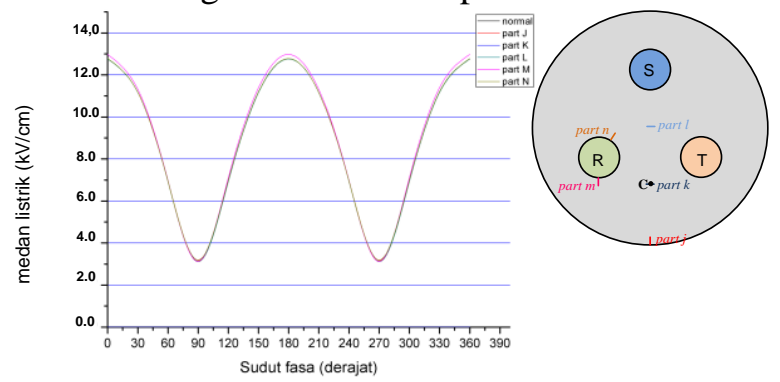

Gambar 19. Medan listrik di titik C dengan keberadaan partikel asing pada posisi yang berbeda-beda

Pada Gambar 19 dapat dilihat besar medan listrik di titik $\mathrm{C}$ dengan variasi letak partikel dalam tangki GIS equilateral. Keberadaan partikel $\mathrm{m}$ menyebabkan besar medan listrik maksimum di titik $\mathrm{C}$ sedikit naik dari kondisi normal, namun keberadaan partikel yang lain tidak terlalu mempengaruhi medan listrik di titik ini.

\subsubsection{Medan listrik di titik $D$ dengan keberadaan partikel asing}

Titik D terletak pada tangki GIS yang berjarak $56.25 \mathrm{~mm}$ dari titik pusat tangki dan segaris vertikal dengan konduktor S, seperti terlihat pada Gambar 20. Pada Tabel 5 dapat dilihat besar medan listrik di titik D yang disebabkan oleh variasi letak partikel.

Pada Gambar 20 dapat dilihat besar medan listrik di titik D dengan variasi letak partikel dalam tangki GIS equilateral.

Tabel 5. Besar medan listrik di titik D pusat GIS dengan memvariasikan letak partikel

\begin{tabular}{c|c|c|c|c|c|c|}
\hline \multirow{2}{*}{$\begin{array}{c}\text { Sudut } \\
\text { fasa } \\
(\theta)^{\circ}\end{array}$} & \multicolumn{5}{|c|}{ Besar medan listrik (kV/cm) di titik dengan } \\
variasi letak partikel \\
\hline 0 & 4.5 & 4.5 & 4.4 & 4.5 & 4.7 & 4.5 \\
30 & 4.5 & 4.5 & 3.9 & 4.5 & 4.5 & 4.5 \\
60 & 4.4 & 4.5 & 2.8 & 4.4 & 4.4 & 4.4 \\
90 & 4.4 & 4.5 & 2.0 & 4.4 & 4.4 & 4.4 \\
120 & 4.4 & 4.5 & 2.8 & 4.4 & 4.6 & 4.4 \\
150 & 4.5 & 4.5 & 3.9 & 4.5 & 4.7 & 4.5 \\
180 & 4.5 & 4.5 & 4.4 & 4.5 & 4.7 & 4.5 \\
210 & 4.5 & 4.5 & 3.9 & 4.5 & 4.5 & 4.5 \\
240 & 4.4 & 4.5 & 2.8 & 4.4 & 4.4 & 4.4 \\
270 & 4.4 & 4.5 & 2.0 & 4.4 & 4.4 & 4.4 \\
300 & 4.4 & 4.5 & 2.8 & 4.4 & 4.6 & 4.4 \\
330 & 4.5 & 4.5 & 3.9 & 4.5 & 4.7 & 4.5 \\
360 & 4.5 & 4.5 & 4.4 & 4.5 & 4.7 & 4.5 \\
\hline
\end{tabular}

Keberadaan partikel mempengaruhi besar dan fasa medan listrik pada titik ini. Partikel $\mathrm{k}$ menyebabkan perubahan nilai maksimum dan nilai minimum yang signifikan. Partikel $m$ dan partikel $\mathrm{n}$ menyebabkan pergeseran fasa medan listrik.

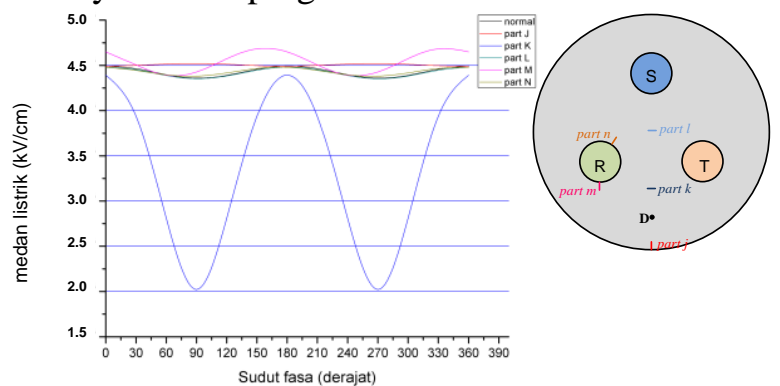

Gambar 20. Medan listrik di titik D dengan keberadaan partikel asing pada posisi yang berbeda-beda 


\subsubsection{Medan listrik di titik $\mathbf{E}$ dengan keberadaan partikel asing}

Titik E terletak pada tangki GIS yang berjarak $74 \mathrm{~mm}$ dari titik pusat tangki dan tegak lurus dengan konduktor S, seperti terlihat pada Gambar 21. Pada Tabel 6 dapat dilihat besar medan listrik di titik E dengan variasi letak partikel.

Tabel 6. Besar medan listrik di titik E pusat GIS dengan memvariasikan letak partikel

\begin{tabular}{|c|c|c|c|c|c|c|}
\hline \multirow{2}{*}{$\begin{array}{c}\text { Sudut } \\
\text { fasa } \\
(\theta)^{\circ}\end{array}$} & \multicolumn{5}{|c|}{ Besar medan listrik (kV/cm) di titik dengan } \\
\cline { 2 - 7 } variasi letak partikel & Normal & Partikel j* & Partikel k & Partikel 1 & Partikel m & Partikel n \\
\hline 0 & 0.2 & 0.0 & 0.1 & 1.9 & 0.2 & 0.2 \\
30 & 1.9 & 0.0 & 1.2 & 3.2 & 1.8 & 1.9 \\
60 & 3.2 & 0.0 & 2.1 & 3.7 & 3.2 & 3.2 \\
90 & 3.7 & 0.0 & 2.4 & 3.2 & 3.8 & 3.7 \\
120 & 3.2 & 0.0 & 2.1 & 1.9 & 3.4 & 3.2 \\
150 & 1.9 & 0.0 & 1.2 & 0.1 & 2.1 & 1.9 \\
180 & 0.2 & 0.0 & 0.1 & 1.9 & 0.2 & 0.2 \\
210 & 1.9 & 0.0 & 1.2 & 3.2 & 1.8 & 1.9 \\
240 & 3.2 & 0.0 & 2.1 & 3.7 & 3.2 & 3.2 \\
270 & 3.7 & 0.0 & 2.4 & 3.2 & 3.8 & 3.7 \\
300 & 3.2 & 0.0 & 2.1 & 1.9 & 3.4 & 3.2 \\
330 & 1.9 & 0.0 & 1.2 & 0.1 & 2.1 & 1.9 \\
360 & 0.2 & 0.0 & 0.1 & 0.1 & 0.2 & 0.2 \\
\hline
\end{tabular}

Pada Gambar 21 dapat dilihat besar medan listrik di titik E dengan variasi letak partikel dalam tangki GIS equilateral. Keberadaan partikel $\mathrm{k}$ menyebabkan nilai maksimum medan listrik pada titik ini menurun. Keberadaan partikel $m$ menyebabkan terjadinya pergeseran fasa medan listrik.

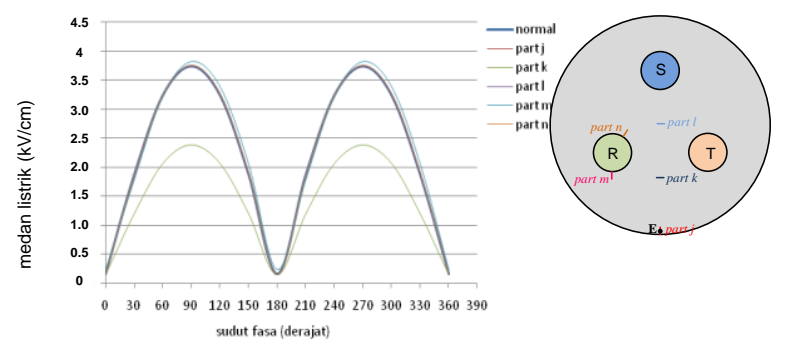

Gambar 21. Medan listrik di titik E dengan keberadaan partikel asing pada posisi yang berbeda-beda

\subsection{Medan listrik maksimum dan minimum pada GIS equilateral 3 fasa dengan keberadaan partikel}

Pada kondisi normal dimana tidak terdapat partikel dalam tangki GIS, medan listrik maksimum terkonsentrasi pada daerah di sekitar konduktor. Setelah melakukan perhitungan, diketahui keberadaaan partikel asing pada medium isolasi GIS, baik itu yang menempel pada permukaan tangki, menempel pada konduktor, ataupun partikel melayang, menyebabkan medan listrik maksimum terkonsentrasi pada ujung-ujung partikel tersebut. Pada Gambar 22 dapat dilihat medan listrik maksimum dalam tangki GIS dalam selang satu siklus tegangan sinusoidal, tanpa partikel dan dengan eksistansi partikel.

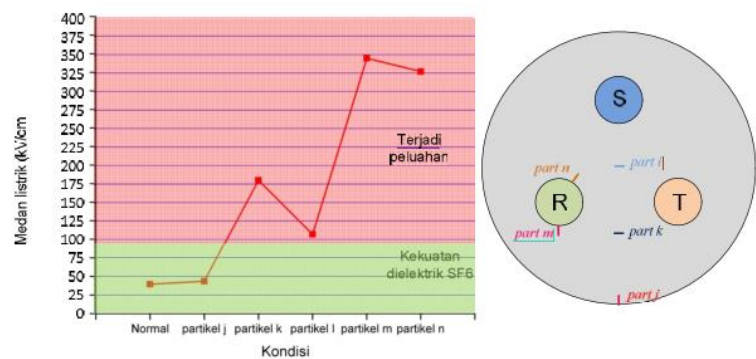

Gambar 22. Medan listrik maksimum pada medium isolasi pada kondisi normal dan pengaruh beberapa partikel pengujian di dalam tangki GIS.

Dari Gambar 22 dapat dilihat keberadaan partikel k, $1, \mathrm{~m}$, dan $\mathrm{n}$ memiliki medan listrik di atas ambang kekuatan dielektrik medium isolasi SF6 sebesar 8.9x106 V/m. Medan listrik yang disebabkan partikel tersebut dapat menyebabkan terjadinya peluahan dalam pada medium isolasi SF6. Hal ini bisa menyebabkan terjadinya kegagalan (breakdown) pada isolasi SF6. Dapat disimpulkan keberadaan partikel tersebut sangat berbahaya terhadap kemampuan isolasi SF6, karena medan listrik saat keberadaan partikel asing melebihi kekuatan dielektrik SF6.

Pada gambar 22, partikel k dan partikel 1 terletak pada posisi berbeda tetapi berjarak sama ke konduktor R dan konduktor T. Kuat medan listrik yang disebabkan oleh kehadiran partikel $\mathrm{k}$ lebih tinggi dibandingkan dengan kehadiran partikel 1. Hal ini berkaitan dengan bentuk lokus pada titiktitik tinjau medan listrik pada GIS equilateral dalam keadaan normal. Sebagaimana telah dideskripsikan, partikel $\mathrm{k}$ terletak di titik $\mathrm{C}$ dan partikel 1 terletak pada titik O. Setelah dibandingkan, bentuk lokus vektor medan listrik di titik $\mathrm{C}$ berbentuk ellips sedangkan bentuk lokus di titik $\mathrm{O}$ berbentuk bulat. Bentuk lokus medan listrik ini menjelaskan bahwa medan listrik maksimum pada titik $\mathrm{C}$ lebih tinggi dibandingkan medan listrik maksimum pada titik $\mathrm{O}$. 


\subsection{Lokus vektor medan listrik}

Besar tegangan pada konduktor-konduktor dalam GIS berbeda-beda selama pemberian tegangan sinusoidal 3 fasa. Hal ini menyebabkan perubahan besar dan arah medan listrik selama siklus tegangan sinusoidal tersebut. Pada sistem GIS 3 fasa ini, konduktor memiliki tegangan yang berbeda fasa, sehingga tidak ada kondisi dimana medan listrik bernilai nol pada ruang di dalam tangki GIS equilateral 3 fasa tersebut. Keberadaan konduktor bertegangan yang memiliki fasa berbeda, menyebabkan terjadinya medan putar.

Tiap titik dalam tangki memiliki medan listrik yang berbeda-beda, terdapat medan listrik bernilai maksimum dan minimum kecuali pada titik $\mathrm{O}$ pada pusat tangki GIS susunan equilateral. Perubahan besar dan arah medan listrik sebagai akibat adanya medan listrik berputar, menghasilkan lokus medan listrik. Lokus ini pada dasarnya berbentuk ellip, namun ada posisi titik tinjau dimana lokus berbentuk bulat dan berbentuk garis. Bentuk dan besarnya lokus berbeda-beda pada tiap titik di dalam tangki GIS equilateral.

Rasio eksentrisitas ( $\eta$ ) adalah perbandingan antara medan listrik minimum dengan medan listrik maksimum pada satu titik tinjau dalam tangki GIS equilateral $\left(\eta=E_{\min } / E_{\max }\right)$. Rasio eksentrisitas ini memiliki nilai dalam selang $0<\eta \leq 1$, nilai mendekati nol maka bentuk lokus seperti garis dan nilai mendekati 1 maka lokus berbentuk bulat, seperti terlihat pada Gambar 23. Semakin tinggi perbedaan antara medan listrik maksimum dan medan listrik minimum, atau rasio eksentrisitas bernilai sangat kecil (mendekati nol), maka bentuk lokus akan semakin ellip, bahkan membentuk suatu garis.

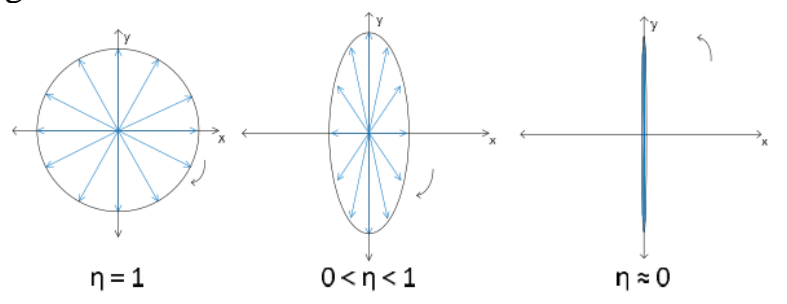

Gambar 23. Bentuk lokus medan listrik berdasarkan nilai rasio eksentrisitas

Pada Gambar 24 dapat dilihat nilai rasio eksentrisitas pada beberapa titik dalam tangki dengan variasi letak partikel. Dari nilai rasio eksentrisitas didapatkan bahwa keberadaan partikel pada medium isolasi mempengaruhi bentuk lokus medan listrik pada beberapa titik dalam tangki GIS. Jarak titik tinjau ke partikel mempengaruhi besar medan maksimum pada titik tersebut, makin dekat jarak titik ke partikel maka makin besar nilai medan maksimum di titik itu. Bentuk lokus menjadi semakin lonjong, seperti medan listrik pada titik B dan titik D, saat terdapat partikel $\mathrm{k}$ pada isolasi gas.

\section{Kesimpulan}

Setelah melakukan perhitungan medan listrik dengan bantuan perangkat lunak menggunakan metode finite element method (FEM) GIS equilateral 3 fasa dengan variasi letak keberadaan partikel didapatkan bahwa keberadaan partikel di dalam tangki GIS equilateral mempengaruhi distribusi medan listrik dalam tangki. Hal ini terlihat dari tingginya intensitas medan listrik terkonsentrasi pada ujung partikel dibandingkan intensitas medan listrik maksimal dalam tangki GIS equilateral dalam keadaan normal. Partikel dalam tangki GIS equilateral juga mempengaruhi bentuk lokus medan listrik yang dihitung dari nilai rasio eksentrisitas. Dari perhitungan didapatkan semakin dekat partikel ke titik tinjau maka bentuk lokus pada titik tinjau tersebut akan semakin pipih. Keberadaan partikel pada posisi antar konduktor dan partikel yang melekat pada konduktor, berbahaya terhadap kemampuan isolasi SF6, karena medan listrik saat keberadaan partikel asing melebihi kekuatan dielektrik SF6 sebesar $89 \mathrm{kV} / \mathrm{cm}$ yang dapat menyebabkan terjadinya partial discharge dan breakdown.

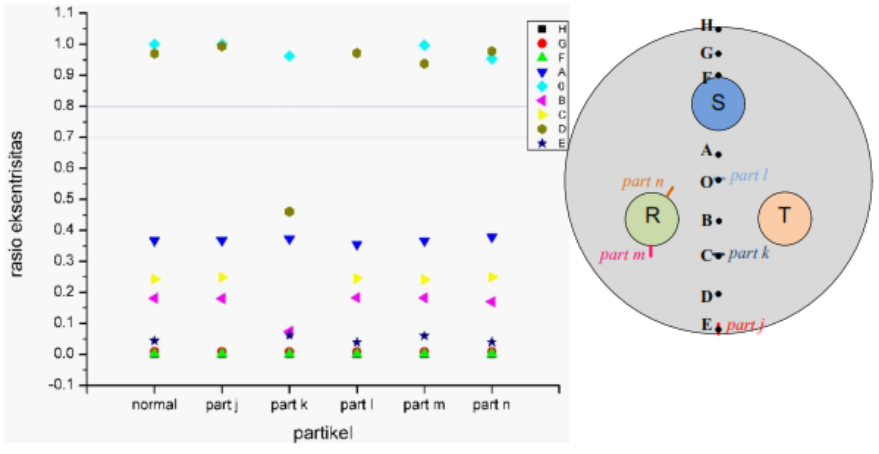

Gambar 24. Rasio eksentrisitas ( $\eta$ ) di beberapa titik dengan variasi letak partikel

\section{Ucapan Terima Kasih (Acknowledgement)}

Penulis berterima kasih atas bantuan yang diberikan oleh Jurusan Teknik Elektro Fakultas Teknik Universitas Andalas untuk mendanai sebagian publikasi ini melalui DIPA FT Unand 2019 (Kontrak No. 095/UN.16.09.D/PL/2020). 


\section{Daftar Pustaka}

[1] Umar Khayam, "Analysis of Distribution, Pattern, and Vector of Electric Field in the Inter Phases Region of Three-phase Gas Insulated Switchgear", International Journal on Electrical Engineering and Informatics Volume 5, Number 4, December 2013.

[2] Umar Khayam, "Rotating Characteristics of Electric Field Vector in Three-phase Power Apparatus", IEEE International Conference on Condition Monitoring and Diagnosis 2327 September 2012, Bali, Indonesia.

[3] Umar Khayam, "Locus and Pattern of Electric FieldVector in the Insulation of Three-phase Gas Insulated Switchgear", IEEE Conference on Power Engineering and Renewable Energy 3-5 July 2012, Bali, Indonesia.

[4] Umar Khayam, "Electric Field Characteristics Inside Three-phase Gas Insulated Switchgear in the Presence of Foreign Metallic Particle", The 4th International Conference on Electrical Engineering and Informatics (ICEEI 2013).

[5] Umar Khayam, Nobuko Otaka, Takakazu Matsuyama, Yoshiki Takehara, Shinya Ohtsuka, Masayuki Hikita, "Examination of Single Phase PDM Device for PD Diagnosis on Three-phase GIS", International Journal on Electrical Engineering and Informatics, Vol. 2 No. 3, pp 244-255, 2010.

[6] S. Yanabu, H. Okubo, S. Matsumoto: "Metallic Particle Motion in Three-phase SF6 Gas Insulated Bus", IEEE Transactions on Power Delivery Vol. PWRD-2, No. 1, pp. 1-6, January 1987.

[7] Umar Khayam, S. Ohtsuka, S. Matsumoto, M. Hikita, "Partial Discharge and Cross Interference Phenomena in a Three-phase Construction", International Journal on Electrical Engineering and Informatics, Vol. 1, No.1, pp. 78-91, 2009.

[8] Umar Khayam, "Investigation of Partial Discharge and Electromagnetic Wave Signal Propagation Characteristics as a Fundamental Study of Diagnosis Technique Improvement on Three-phase Gas Insulated System". Doctoral Dissertation. Department of Electrical and Electronic Engineering, Graduate School of Engineering Kyushu, Institute of Technology December, 2007
[9] Nagbhushan, J. Amarnath, D. Subbarayudu, "Analysis of Electric Field Intensity in Gas Insulated Busduct". International Journal of Engineering Research and Applications (IJERA) Vol. 2, Issue 5, September- October 2012, pp.1756-17160.

[10] M. Ramya Priya, G.V. Nageshkumar, J. Amarnath, R. Prabhadevi, "Effect of various design parameters of Gas Insulated Busduct in the performance of Gas Insulated Substations", International Conference on Control, Automation, Communication and Energy Conservation, 4th-6 th June 2009.

[11] Swarnalatha, Nattava, J.Amaranath. "Random Movement of Particle Trajectories In A Gas Insulated Bus Duct". International Journal of Advanced Research in Electrical, Electronics and Instrumentation Engineering. Vol. 2, Issue 12, December 2013.

[12] Adolf J. Schwab. "Field Theory Concept". Springer-Verlag Berlin Heidelberg, 1988.

[13] K.V.S.R. Subrahmanyam, J. Amarnath. "Conducting Particle Contamination in a Gas Insulated Substation (GIS) With Image Charge of the Conductor". Journal of Emerging Trends in Engineering and Applied Sciences (JETEAS) 2 (3): 451-455. Scholarship Research Institute Journal, 2011.

[14] Y. Takahashi, "Diagnostic Methods For GasInsulated Substations". IEEE Transactions on Electrical Insulation Vol. EI-21 No.6, December 1986.

[15] N. Swarna Latha, J. Amarnath, "Determination of Particle Trajectories in a Gas Insulated Busduct (GIB)". International Journal of Soft Computing and Engineering (IJSCE). ISSN: 2231-2307, Volume-3, Issue-6, January 2014

[16] P. Nagarjuna Reddy, J. Amarnath, "Effect of Particle Dimensions on Its Movement in Three Phase Gas Insulated Busduct". International Journal of Engineering Research and Applications. ISSN : 22489622, Vol. 3, Issue 6, Nov-Dec 2013, pp.891-896

[17] P. Ponchon, O. Chuniaud, R.Pages, "Comparison Of Environmental Impact Of Singlephase Or Three-Phase Design For 245kv GIS”. MatPost 2007. 


\section{Biodata Penulis}

Rizki Wahyu Pratama, adalah staf pengajar Jurusan Teknik Elektro Fakultas Teknik Universitas Andalas Padang. Lulus Program Sarjana tahun 2011 pada Bidang Teknik Tenaga Listrik Jurusan Teknik Elektro Fakultas Teknik Universitas Andalas. Pada tahun 2014 menyelesaikan studi program magister bidang di STEI ITB Bandung.

Hanalde Andre, adalah staf pengajar Jurusan Teknik Elektro Fakultas Teknik Universitas Andalas Padang sejak tahun 2015. Lulus Program Sarjana tahun 2011 pada Bidang Teknik Tenaga Listrik Jurusan Teknik Elektro Fakultas Teknik Universitas Andalas. Pada tahun 2013 menyelesaikan studi program magister bidang di STEI ITB Bandung.

Umar Khayam, adalah staf pengajar Jurusan Teknik Elektro Sekolah Tinggi Elektro dan Informatika Institut Teknologi Bandung. Lulus Program Sarjana Teknik Elektro tahun 1998 dan tahun 2000 Program Magister Teknik Elektro Insitut Teknologi Bandung. Pada tahun 2008 menyelesaikan studi Doktor di Khusyu Institut of Teknology Japan, Jepang. 